\title{
Cerebral venous thrombosis as a diagnostic challenge: Clinical and radiological correlation based on the retrospective analysis of own cases
}

\author{
Anna Zimny 1, A-D, F, Edyta Dziadkowiak2, B-D, F, Joanna Bladowska", (-F, Justyna Chojdak-Łukasiewicz², B-D, F, \\ Aleksandra Loster-Niewińska ${ }^{2, B-D, F}$, Marek Sąsiadek ${ }^{1, A, E, F}$, Bogusław Paradowski ${ }^{3, A, E, F}$ \\ ${ }^{1}$ Department of General and Interventional Radiology and Neuroradiology, Wroclaw Medical University, Poland \\ ${ }^{2}$ Department of Neurology, Medical University Hospital, Wrocław, Poland \\ ${ }^{3}$ Department of Neurology, Wroclaw Medical University, Poland \\ A - research concept and design; $B$ - collection and/or assembly of data; $C$ - data analysis and interpretation; \\ $D$ - writing the article; $E$ - critical revision of the article; $F$ - final approval of article
}

Address for correspondence

Joanna Bladowska

E-mail: asia.bladowska@gmail.com

Funding sources

None declared

\section{Conflict of interest}

None declared

\section{Acknowledgements}

The authors thank the Experimental Research Center of Canakkale Onsekiz Mart University.

Received on March 4, 2015

Revised on March 24, 2015

Accepted on April 24, 2015

\begin{abstract}
Background. Cerebral venous thrombosis (CVT) is a rare condition which constitutes $0.5-1 \%$ of all strokes. The clinical and radiological picture of CVT is non-specific and can mimic other disorders.

Objectives. The aim of the study was to retrospectively evaluate and correlate clinical and radiological symptoms presented by patients with CVT, both in the initial and follow-up neurological and neuroimaging examinations, with a special emphasis on diagnostic difficulties.
\end{abstract}

Material and methods. Material consisted of 11 patients with CVT (7 women, 4 men). The average age was 43.5, ranging from 23 to 69 years. Clinical symptoms, laboratory findings, risk factors and the results of neuroimaging examinations including $\mathrm{CT}, \mathrm{MRl}$ and DSA were retrospectively analyzed and correlated.

Results. All subjects developed superficial CVT and 1 also deep CVT, with no parenchymal lesions in 2 cases, non-hemorrhagic infarctions in 3 and hemorrhagic lesions in 6 subjects. The most frequent symptoms were headache, seizures and hemiparesis. The major risk factors were hormonal therapies in women and congenital thrombophilia. Factors influencing the clinical course and outcome the most were location and type of brain lesions, with hemorrhagic cortical infarctions bringing the worst prognosis and being associated with the highest rate of persistent neurological deficits, despite the rate of vessel recanalization.

Conclusions. In our opinion, quick diagnosis before parenchymal hemorrhagic lesions are visible on CT is of crucial importance and requires a constant alertness and good cooperation of neurologists and radiologists, especially in emergency settings.

Key words: cerebral venous thrombosis, headache, diagnostic imaging

DOI

$10.17219 /$ acem/66778

Copyright

Copyright by Author(s)

This is an article distributed under the terms of the

Creative Commons Attribution Non-Commercial License

(http://creativecommons.org/licenses/by-nc-nd/4.0/) 
Cerebral venous thrombosis (CVT) is a rare condition which constitutes $0.5-1 \%$ of all strokes and may involve both intracranial veins and sinuses. ${ }^{1,2}$ The clinical picture of CVT is non-specific and can mimic other neurological disorders. The most common neurological symptoms include headache or features of increased intracranial pressure as well as seizures and focal neurological deficits, which depend on the location of cerebral lesions. ${ }^{3}$ Involvement of the superior sagittal sinus usually leads to motor deficits and seizures while thrombosis of the left transverse sinus may cause aphasia. Rare symptoms include cavernous sinus syndrome (exophthalmos, conjunctival edema and painful ophthalmoplegia), tinnitus, isolated psychiatric symptoms and cranial nerve palsies. ${ }^{4}$

The etiology of CVT is very similar to that of deep vein thrombosis in the legs and can be divided into non-infectious and infectious factors. The non-infectious factors are oral contraceptives, pregnancy and puerperium, hormonal disorders, severe dehydration, cancer, connective tissue disease, trauma and neurosurgical procedures as well as hematological disorders such as deficiency of protein $\mathrm{C}, \mathrm{S}$ or antithrombin III, mutations of factor V Leyden or prothrombin genes and essential thrombocythemia or polycythemia. The tendency to thrombosis also occurs in antiphospholipid syndrome, circulatory disorders, and in the course of prolonged immobilization of the patient. Central nervous system or ear infections, sinusitis, endocarditis and sepsis are the most common infectious risk factors of CVT. ${ }^{1,5,6}$ In $44 \%$ of CVT patients, more than 1 risk factor may be found while in $15 \%$ the etiology of CVT remains unknown. ${ }^{7}$

Due to non-specific clinical symptoms, neuroimaging examinations play a major role in the initial diagnosis of CVT. Since CVT patients usually develop acute neurological symptoms, the first imaging examination is $\mathrm{CT}$ of the brain in the emergency department. CVT affects cerebral veins and dural sinuses, and perhaps leads to lesions within brain parenchyma such as edema or venous infarction. To visualize the whole extent of the disease, an initial CT examination of the brain is often followed by other imaging examinations such as CT venography, magnetic resonance (MR) with or without contrast injection, MR venography (MRV) and, very rarely, digital subtracted angiography (DSA). ${ }^{8,9}$ Accurate diagnosis of CVT allows for quick implementation of treatment and better prognosis for the patient. ${ }^{10}$

It has to be stressed that despite the growing knowledge of this disease, the diagnosis of CVT is still commonly overlooked and delayed due to the remarkable diversity of clinical symptoms and neuroimaging appearance, and thus still remains a diagnostic challenge for both clinicians and radiologists.

The aim of the study was to retrospectively evaluate and correlate clinical and radiological symptoms presented by patients with CVT both in the initial and follow-up neurological and neuroimaging examinations, with a special emphasis on diagnostic difficulties.

\section{Material and methods}

Eleven patients with CVT (7 women, 4 men) hospitalized in the Department of Neurology at Wroclaw Medical University between 2009 and 2014 were involved in the retrospective study. The average age was 43.5, ranging from 23 to 69 years. All patients underwent detailed neurological evaluation by experienced neurologists as well as laboratory examinations including the assessment of the coagulation parameters.

All patients underwent several neuroimaging examinations, including CT and MR examinations in all subjects and DSA in 2 cases. All CT examinations were performed using a 64 row scanner (GE Healthcare) with a slice thickness of $0.625 \mathrm{~mm}$, and included unenhanced and contrast enhanced CT examinations as well as CT venography. All MR examinations were performed using a 1.5 T MR scanner (Signa Hdx GE). The analyzed MR examinations included standard MR examinations (T1-, T2-weighted images, FLAIR sequence, diffusion weighted imaging - DWI, susceptibility weighted imaging - SWI), without or with contrast administration, as well as MR venography (MRV) using a 3D Time of Flight (TOF) sequence. The study was conducted in accordance with the guidelines of the University Ethics Committee for conducting research involving humans. Each patient provided signed informed consent to participate in the examination.

Clinical symptoms, laboratory findings, risk factors and the results of neuroimaging examinations were retrospectively analyzed. Neurological examinations and neuroimaging examinations were performed on admission and then several times during the follow-up period. The follow-up period ranged from 2 weeks to 45 months (mean 39 weeks). A constant monitoring after hospitalization covered 9 patients with CVT, with the observation time ranging from 8 weeks to 45 months. Two patients did not present themselves for follow-up examinations after hospitalization.

\section{Results}

\section{Clinical symptoms}

The most common clinical symptoms prior to hospitalization were severe headache (8 patients), hemiparesis (7 patients) and loss of consciousness with seizures (6 patients). In 2 subjects headache was the only symptom, in the rest headache was accompanied by other symptoms such as epilepsy ( 2 subjects), hemiparesis ( 2 subjects) or both epilepsy and hemiparesis (2 subjects). Three patients showed aphasic speech disorders, and 1 patient experienced visual phenomena and transient prosopagnosia (Tables 1-3).

Follow-up examinations revealed overall improvement in the neurological status of all patients. Four patients fully recovered and showed no neurological symptoms and deficits, 2 patients developed persistent hemiparesis, 
3 patients secondary epilepsy and 2 subjects both hemiparesis and secondary epilepsy (Tables $1-3$ ).

\section{Laboratory findings}

Laboratory tests carried out on admission revealed slightly elevated levels of C-reactive protein (CRP) and leukocytes in 3 patients, elevated levels of D-dimers (2.12$22.06 \mu \mathrm{L} / \mathrm{mL}$ ) in 5 subjects and elevated levels of fibrinogen $(4.7-7.5 \mathrm{~g} / \mathrm{L})$ in 4 patients. Only 3 of 11 patients revealed abnormalities in coagulation status such as resistance to activated protein $\mathrm{C}$, protein $\mathrm{S}$ deficiency and prothrombin G2021A mutation. Three patients underwent CSF examination which showed elevated protein levels in 2 subjects.

\section{Risk factors}

Risk factors of CVT were established in 8 patients while in 3 cases no risk factors were found. The most frequent risk factors were hormonal therapies (oral contracep-

Table 1. Neurological and radiological findings in patients with no brain lesions due to cerebral venous thrombosis

\begin{tabular}{|c|c|c|c|c|c|c|}
\hline $\begin{array}{l}\text { Patient } \\
\text { No. }\end{array}$ & $\begin{array}{l}\text { Age, } \\
\text { sex }\end{array}$ & $\begin{array}{l}\text { Location of vascular and } \\
\text { parenchymal changes based } \\
\text { on neuroimaging studies }\end{array}$ & $\begin{array}{l}\text { Neurological status on } \\
\text { admission and before }\end{array}$ & Risk factors & $\begin{array}{l}\text { Follow-up } \\
\text { neuroimaging } \\
\text { studies }\end{array}$ & $\begin{array}{l}\text { Neurological status } \\
\text { in the follow-up } \\
\text { examinations }\end{array}$ \\
\hline 1. & $\begin{array}{l}40 \text { years, } \\
\text { female }\end{array}$ & $\begin{array}{l}\text { vessels: right IJV, transverse } \\
\text { and sigmoid sinuses with } \\
\text { infratentorial cortical veins and } \\
\text { posterior aspect of superior } \\
\text { sagittal sinus with left draining } \\
\text { cortical veins } \\
\text { brain: no lesions }\end{array}$ & $\begin{array}{l}\text { admission: severe headache, } \\
\text { normal neurological } \\
\text { examination } \\
\text { before: severe headache lasting } \\
\text { for a few days }\end{array}$ & $\begin{array}{l}\text { hormonal infertility } \\
\text { treatment, } \\
\text { prothrombin } \\
\text { G20210A mutation }\end{array}$ & $\begin{array}{l}\text { after } 9 \text { weeks } \\
(\mathrm{MR}+\mathrm{C}+\mathrm{MRV}) \\
\text { vessels: partial } \\
\text { recanalization }\end{array}$ & $\begin{array}{c}\text { after } 9 \text { weeks } \\
\text { normal neurological } \\
\text { examination, } \\
\text { no neurological } \\
\text { symptoms }\end{array}$ \\
\hline 2. & $\begin{array}{l}23 \text { years, } \\
\text { male }\end{array}$ & $\begin{array}{l}\text { vessels: right transverse and } \\
\text { sigmoid sinuses, IJV } \\
\text { brain: no lesions due to cerebral } \\
\text { venous thrombosis }\end{array}$ & $\begin{array}{l}\text { admission: severe headache, } \\
\text { peripheral damage of the } 7^{\text {th }} \\
\text { nerve on the right, right-sided } \\
\text { hearing loss due to right } \\
\text { temporal bone fracture } \\
\text { before: severe head injury } \\
5 \text { days earlier }\end{array}$ & $\begin{array}{l}\text { fracture of the right } \\
\text { temporal bone } \\
\text { close to the right } \\
\text { sigmoid sinus }\end{array}$ & $\begin{array}{l}\text { after } 9 \text { weeks } \\
(\mathrm{MR}+\mathrm{C}+\mathrm{MRV}) \\
\text { vessels: total } \\
\text { recanalization }\end{array}$ & $\begin{array}{c}\text { after } 9 \text { weeks } \\
\text { normal } \\
\text { neurological } \\
\text { examination, } \\
\text { no neurological } \\
\text { symptoms }\end{array}$ \\
\hline
\end{tabular}

IJV - internal jugular vein; MR + C + MRV - MR examination with MR venography and contrast administration.

Table 2. Neurological and radiological findings in patients with non-hemorrhagic brain lesions due to cerebral venous thrombosis

\begin{tabular}{|c|c|c|c|c|c|c|}
\hline $\begin{array}{l}\text { Patient } \\
\text { No. }\end{array}$ & $\begin{array}{l}\text { Age, } \\
\text { sex }\end{array}$ & $\begin{array}{l}\text { Location of vascular and } \\
\text { parenchymal changes based } \\
\text { on neuroimaging studies }\end{array}$ & $\begin{array}{l}\text { Neurological status on } \\
\text { admission and before }\end{array}$ & Risk factors & $\begin{array}{c}\text { Follow-up } \\
\text { neuroimaging studies }\end{array}$ & $\begin{array}{l}\text { Neurological status } \\
\text { in the follow-up } \\
\text { examinations }\end{array}$ \\
\hline 3. & $\begin{array}{l}42 \text { years, } \\
\text { female }\end{array}$ & $\begin{array}{l}\text { vessels: left vein of Labbe, } \\
\text { transverse and sigmoid } \\
\text { sinuses, IJV } \\
\text { brain: non-hemorrhagic edema } \\
\text { within the cortex of the left } \\
\text { temporo-parieto-occipital } \\
\text { region }\end{array}$ & $\begin{array}{l}\text { admission: sudden speech } \\
\text { impairment, mixed aphasia, } \\
\text { moderate right-sided } \\
\text { hemiparesis } \\
\text { before: no symptoms }\end{array}$ & not found & $\begin{array}{l}\text { after } 2 \text { weeks } \\
\text { (MR }+C+M R V) \\
\text { vessels: no recanalization } \\
\text { brain: non-hemorrhagic } \\
\text { edema in the left } \\
\text { temporo-parieto- } \\
\text { occipital region }\end{array}$ & $\begin{array}{l}\text { after } 2 \text { weeks } \\
\text { mild right-sided } \\
\text { hemiparesis, no } \\
\text { further follow-up } \\
\text { available }\end{array}$ \\
\hline 4. & $\begin{array}{l}40 \text { years, } \\
\text { female }\end{array}$ & $\begin{array}{l}\text { vessels: anterior aspect of the } \\
\text { superior sagittal sinus and left } \\
\text { draining cortical veins } \\
\text { brain: non-hemorrhagic edema } \\
\text { within the cortex of the left } \\
\text { frontal lobe }\end{array}$ & $\begin{array}{l}\text { admission: generalized seizures } \\
\text { with tongue biting, normal } \\
\text { neurological examination } \\
\text { before: severe headache and } \\
\text { behavioral changes for a few } \\
\text { days }\end{array}$ & $\begin{array}{l}\text { oral } \\
\text { contraception, } \\
\text { protein S } \\
\text { deficiency }\end{array}$ & $\begin{array}{l}\text { after } 9 \text { weeks } \\
(M R+C+M R V) \\
\text { vessels: total } \\
\text { recanalization } \\
\text { brain: no visible lesions }\end{array}$ & $\begin{array}{l}\text { after } 9 \text { weeks } \\
\text { symptomatic } \\
\text { epilepsy, normal } \\
\text { neurological } \\
\text { examination }\end{array}$ \\
\hline 5. & $\begin{array}{l}31 \text { years, } \\
\text { female }\end{array}$ & $\begin{array}{l}\text { vessels: left vein of Labbe, } \\
\text { transverse and sigmoid sinuses, IJV } \\
\text { deep venous system: straight } \\
\text { sinus, vein of Galen, internal } \\
\text { veins of the } 3^{\text {rd }} \text { ventricle, inferior } \\
\text { sagittal sinus } \\
\text { brain: non-hemorrhagic edema } \\
\text { of the left thalamus, caudate } \\
\text { nucleus and left periventricular } \\
\text { white matter }\end{array}$ & $\begin{array}{l}\text { admission: sudden transient } \\
\text { loss of consciousness, mild } \\
\text { mixed aphasia and mild right } \\
\text { hand hemiparesis with positive } \\
\text { right Babinski sign } \\
\text { before: severe headache of the } \\
\text { left temporo-occipital region } \\
\text { with nausea and vomiting for } \\
\text { a week }\end{array}$ & $\begin{array}{l}\text { oral } \\
\text { contraception }\end{array}$ & $\begin{array}{l}\text { after } 8.5 \text { months } \\
(\mathrm{MR}+\mathrm{C}+\mathrm{MRV}) \\
\text { vessels: total } \\
\text { recanalization } \\
\text { brain: small T2- } \\
\text { hyperintense foci within } \\
\text { the left periventricular } \\
\text { white matter }\end{array}$ & $\begin{array}{l}\text { after } 8.5 \text { months } \\
\text { normal neurological } \\
\text { examination, } \\
\text { no neurological } \\
\text { symptoms }\end{array}$ \\
\hline
\end{tabular}


Table 3. Neurological and radiological findings in patients with hemorrhagic brain lesions due to cerebral venous thrombosis

\begin{tabular}{|c|c|c|c|c|c|c|}
\hline $\begin{array}{l}\text { Patient } \\
\text { No. }\end{array}$ & $\begin{array}{l}\text { Age, } \\
\text { sex }\end{array}$ & $\begin{array}{l}\text { Location of vascular and } \\
\text { parenchymal changes based } \\
\text { on neuroimaging studies }\end{array}$ & $\begin{array}{l}\text { Neurological status on } \\
\text { admission and before }\end{array}$ & Risk factors & $\begin{array}{l}\text { Follow-up } \\
\text { neuroimaging studies }\end{array}$ & $\begin{array}{l}\text { Neurological status } \\
\text { in the follow-up } \\
\text { examinations }\end{array}$ \\
\hline 6. & $\begin{array}{l}29 \text { years, } \\
\text { female }\end{array}$ & $\begin{array}{l}\text { vessels: superior sagittal sinus } \\
\text { with draining cortical veins, } \\
\text { bilateral transverse and sigmoid } \\
\text { sinuses, bilateral IJVs } \\
\text { brain: hemorrhagic infarction in } \\
\text { the right frontal lobe }\end{array}$ & $\begin{array}{l}\text { admission: transient loss of } \\
\text { consciousness two times, } \\
\text { generalized seizures with } \\
\text { convulsions, mild left-sided } \\
\text { hemiparesis } \\
\text { before: severe headache for } \\
\text { a few days }\end{array}$ & $\begin{array}{l}\text { caesarean } \\
\text { section } 10 \\
\text { days earlier, } \\
\text { resistance to } \\
\text { the activated } \\
\text { protein C }\end{array}$ & $\begin{array}{l}\text { after } 3.5 \text { months } \\
\text { (MR }+C+\text { MRV }) \\
\text { vessels: total } \\
\text { recanalization } \\
\text { brain: postinfarction } \\
\text { malacia within the cortex } \\
\text { of the right frontal lobe }\end{array}$ & $\begin{array}{l}\text { after } 3.5 \text { months } \\
\text { symptomatic } \\
\text { epilepsy, mild } \\
\text { mouth asymmetry } \\
\text { on the left side }\end{array}$ \\
\hline 7. & $\begin{array}{l}49 \text { years, } \\
\text { male }\end{array}$ & $\begin{array}{l}\text { vessels: superior sagittal sinus, } \\
\text { bilateral transverse and sigmoid } \\
\text { sinuses, straight sinus, right vein } \\
\text { of Trolard } \\
\text { brain: } 2 \text { bilateral fronto-parietal } \\
\text { hemorrhagic infarctions }\end{array}$ & $\begin{array}{l}\text { admission: complex partial } \\
\text { seizures with moderate left } \\
\text { side hemiparesis, psychomotor } \\
\text { slowing } \\
\text { before: severe headache }\end{array}$ & $\begin{array}{l}\text { malignant } \\
\text { melanoma } \\
\text { with distant } \\
\text { metastases }\end{array}$ & $\begin{array}{l}\text { after } 23 \text { days }(\mathrm{CT}) \\
\text { vessels: unknown status } \\
\text { brain: blood resolution } \\
\text { within infarctions }\end{array}$ & $\begin{array}{l}\text { after } 23 \text { days } \\
\text { motor aphasia, } \\
\text { mild right-sided } \\
\text { hemiparesis }\end{array}$ \\
\hline 8. & $\begin{array}{l}36 \text { years, } \\
\text { female }\end{array}$ & $\begin{array}{l}\text { vessels: right vein of Labbe, } \\
\text { transverse and sigmoid } \\
\text { sinuses, IJV } \\
\text { brain: right fronto-temporal } \\
\text { cortical hemorrhagic infarction }\end{array}$ & $\begin{array}{l}\text { admission: generalized seizures, } \\
\text { mouth asymmetry on the right } \\
\text { side, delays in the left upper } \\
\text { limb in the Barre attempt } \\
\text { before: severe headache of the } \\
\text { occipital region for a few days, }\end{array}$ & $\begin{array}{l}\text { oral } \\
\text { contraception }\end{array}$ & $\begin{array}{l}\text { after } 34 \text { months } \\
(C T+C T A) \\
\text { vessels: total } \\
\text { recanalization } \\
\text { brain: postinfarction } \\
\text { malacia in the right } \\
\text { temporal cortex }\end{array}$ & $\begin{array}{l}\text { after } 34 \text { months } \\
\text { symptomatic } \\
\text { epilepsy, normal } \\
\text { neurological } \\
\text { examination }\end{array}$ \\
\hline 9. & $\begin{array}{l}59 \text { years, } \\
\text { female }\end{array}$ & $\begin{array}{l}\text { vessels: right superior sagittal } \\
\text { sinus, transverse and sigmoid } \\
\text { sinus, IJV } \\
\text { brain: left fronto-temporal } \\
\text { cortical hemorrhagic infarction } \\
\text { with large mass effect and } \\
\text { regional SAH }\end{array}$ & $\begin{array}{l}\text { admission: focal seizures, } \\
\text { conscious, deep sensorimotor } \\
\text { aphasia, moderate right-sided } \\
\text { hemiparesis with a positive right } \\
\text { Babinski sign } \\
\text { before: mixed aphasia and mild } \\
\text { right-sided hemiparesis } \\
\text { for } 2 \text { days }\end{array}$ & $\begin{array}{l}\text { colon cancer } \\
\text { treated with } \\
\text { radio and } \\
\text { chemotherapy } \\
2 \text { years earlier } \\
\text { no other risk } \\
\text { factors found }\end{array}$ & $\begin{array}{l}\text { after } 45 \text { months } \\
(\mathrm{MR}+\mathrm{C}+\mathrm{MRV}) \\
\text { vessels: partial } \\
\text { recanalization } \\
\text { brain: post-infarction } \\
\text { malacia in the left } \\
\text { temporal cortex }\end{array}$ & $\begin{array}{l}\text { after } 45 \text { months } \\
\text { symptomatic } \\
\text { epilepsy, } \\
\text { sensorimotor } \\
\text { aphasia, mild right- } \\
\text { sided hemiparesis }\end{array}$ \\
\hline 10. & $\begin{array}{l}69 \text { years, } \\
\text { male }\end{array}$ & $\begin{array}{l}\text { vessels: right transverse and } \\
\text { sigmoid sinuses, IJV } \\
\text { brain: right occipital cortical/ } \\
\text { subcortical hemorrhagic } \\
\text { infarction }\end{array}$ & $\begin{array}{l}\text { admission: visual phenomena, } \\
\text { bradyphrenia, transient } \\
\text { prosopagnosia, mild left-sided } \\
\text { hemiparesis } \\
\text { before: headache for } 2 \text { weeks }\end{array}$ & not found & $\begin{array}{l}\text { after } 8 \text { months } \\
(\mathrm{MR}+\mathrm{C}+\mathrm{MRV}) \\
\text { vessels: partial } \\
\text { recanalization } \\
\text { brain: post-infarction } \\
\text { malacia within the right } \\
\text { occipital cortex }\end{array}$ & $\begin{array}{l}\text { after } 8 \text { months } \\
\text { normal neurological } \\
\text { examination, } \\
\text { no neurological } \\
\text { symptoms }\end{array}$ \\
\hline 11. & $\begin{array}{l}61 \text { years, } \\
\text { male }\end{array}$ & $\begin{array}{l}\text { vessels: anterior aspect of the } \\
\text { superior sagittal sinus } \\
\text { brain: left frontal hemorrhagic } \\
\text { infarction }\end{array}$ & $\begin{array}{l}\text { admission: increasing memory } \\
\text { and orientation impairment, } \\
\text { psychomotor slowing, mild } \\
\text { right-side hemiparesis } \\
\text { before: first generalized } \\
\text { seizures } 2 \text { months earlier }\end{array}$ & not found & $\begin{array}{l}\text { after } 8 \text { months } \\
(M R+C+M R V) \\
\text { vessels: no } \\
\text { recanalization } \\
\text { brain: post-infarction } \\
\text { malacia in the cortex of } \\
\text { the left frontal lobe }\end{array}$ & $\begin{array}{l}\text { after } 8 \text { months } \\
\text { symptomatic } \\
\text { epilepsy, mild right- } \\
\text { sided hemiparesis }\end{array}$ \\
\hline
\end{tabular}

IJV - internal jugular vein; MR + C + MRV - MR examination with MR venography and contrast administration.

tives, infertility treatment) found in 4 cases, followed by abnormalities in the coagulation process in 3 cases, neoplasmatic process in 2 patients, a fracture of the temporal bone in 1 patient and a cesarean section in 1 case. In 3 cases of female patients, several risk factors were present such as a cesarean section and resistance to activated protein $\mathrm{C}$, hormonal infertility treatment coexisting with prothrombin G20210A mutation, or oral contraception with a protein S deficiency (Tables 1-3).

\section{Treatment}

Immediately after admission, all patients received symptomatic treatment depending on the patient's condition and symptoms, i.e., treatment of intracranial hypertension, seizures or headache. After the final diagnosis of CVT, according to the recommendations of the European Federation of Neurological Societies, all patients received body-weight adjusted subcutaneous low-molecular-weight 
Table 4. Initial diagnosis and a list of neuroimaging studies performed in patients with cerebral venous thrombosis during hospitalization. A neuroimaging examination which enabled a correct diagnosis is indicated in bold

\begin{tabular}{|c|c|c|}
\hline Patient number & First radiological diagnosis based on an emergency CT & Neuroimaging studies during hospitalisation \\
\hline 1. & cerebral venous thrombosis & $\mathrm{CT}\left(1^{\text {st }}\right.$ day $), C T V, M R+C+M R V$ \\
\hline 2. & temporal bone fracture, artefacts & $\mathrm{CT}, \mathrm{CT}\left(2^{\text {nd }}\right.$ day) $, \mathrm{CTV}, \mathrm{MR}+\mathrm{C}$ \\
\hline 3. & cerebral venous thrombosis & $\mathrm{CT}\left(1^{\text {st }}\right.$ day $), \mathrm{CTV}, \mathrm{MR}+\mathrm{C}+\mathrm{MRV}$ \\
\hline 4. & normal & $C T, M R+C\left(6^{\text {th }}\right.$ day $)$ \\
\hline 5. & normal & $C T, C T, C T+C\left(5^{\text {th }}\right.$ day) $, C T V, M R+C+M R V, C T, C T V$ \\
\hline 6. & bleeding vascular malformation & $C T, D S A, M R+C\left(5^{\text {th }}\right.$ day $), C T+C$ \\
\hline 7. & hemorrhagic metastases & $C T+C, C T, C T+C\left(8^{\text {th }}\right.$ day $), M R, C T$ \\
\hline 8. & normal & $C T, C T V, M R+C\left(8^{\text {th }}\right.$ day $), M R, C T$ \\
\hline 9. & unequivocal diagnosis: hemorrhagic ischemic or venous infarction or brain contusion & $C T+C, C T V\left(3^{\text {rd }}\right.$ day), CT, CT \\
\hline 10. & hemorrhagic brain contusion & $C T, C T+C, M R+C\left(13^{\text {th }}\right.$ day $), M R, M R+C$ \\
\hline 11. & unequivocal: hemorrhagic brain contusion or metastases & $C T, M R+C, C T V, D S A\left(21^{\text {st }}\right.$ day $)$ \\
\hline
\end{tabular}

CT - unenhanced computed tomography; CT + C - contrast enhanced computed tomography; CTV - computed tomography venography; MR - unenhanced magnetic resonanse; $\mathrm{MR}+\mathrm{C}$ - contrast enhanced magnetic resonanse; MRV - magnetic resonance venography; DSA - digital subtracted angiography.

heparin at therapeutic doses and transitioned to vitamin $\mathrm{K}$ antagonist. ${ }^{11}$ After discharge, all patients were on oral anticoagulants based on a moderate international normalized target ratio (INR) between 2.0 and 3.0. The duration of the treatment depended on the risk factors. All patients with provoked CVT, associated with transient risk factors such as head trauma and oral contraceptives, were treated with a vitamin $\mathrm{K}$ antagonist for 3 months. Patients with unprovoked CVT received therapeutic anticoagulation for 6-12 months. Patients with thrombophilia were treated for 6-12 months and in these cases indefinite anticoagulation therapy should be considered. In 5 cases, additional antiepileptic drugs were included in the constant therapy because of the diagnosis of secondary epilepsy.

\section{Neuroimaging examinations}

All patients underwent an emergency CT scan of the brain, in 9 cases without intravenous contrast injection and in 2 cases with contrast administration. On the basis of the emergency brain CT, only 2 patients were correctly diagnosed with CVT. In the remaining patients, other diagnoses were suggested such as bleeding vascular malformation (1 subject), hemorrhagic metastases ( 1 subject) or hemorrhagic cerebral contusion (1 subject). In 2 patients, the CT images were reported as inconclusive requiring differentiation between hemorrhagic arterial or venous infarction, cerebral contusion or hemorrhagic metastasis. In 1 patient after a severe head trauma, signs of CVT were overlooked due to motion artefacts. In 3 patients, the CT examinations were reported as normal (Table 4).
During hospitalization, all patients underwent several neuroimaging examinations such as $\mathrm{CT}$ with or without contrast administration, CT venography, MRI with or without contrast administration, MR venography (MRV) and digital subtracted angiography (DSA) (Table 4, Fig. 1-3). In 9 patients, a correct diagnosis of CVT was established in the follow-up examinations, such as unenhanced CT (in 1 subject on the $2^{\text {nd }}$ day), contrast enhanced CT (in 2 subjects on the $5^{\text {th }}$ and $8^{\text {th }}$ day), CT venography (in 1 subject on the $3^{\text {rd }}$ day), contrast enhanced MRI (in 4 subjects on the $5^{\text {th }}, 6^{\text {th }}, 8^{\text {th }}$ and $13^{\text {th }}$ day), and in DSA (in 1 subject on the $21^{\text {st }}$ day). Diagnosis of CVT took an average of 6.6 days (from 1 to 21 days). Only in 2 patients was CVT diagnosed during the first neuroimaging examination, the rest of the

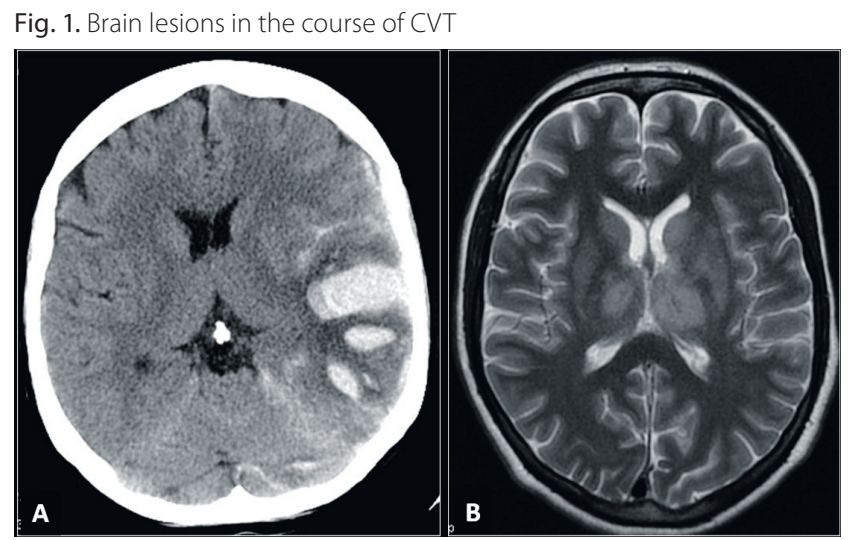

a - a CT image showing typical hemorrhagic venous infarction in the left temporal lobe; b-T2-weighted MR image showing non-hemorrhagic edema within the left basal ganglia region and both thalami due to thrombosis of the deep venous system, which was not visible in the follow-up MR examinations 
Fig. 2. Imaging of thrombosed vessels with CT techniques

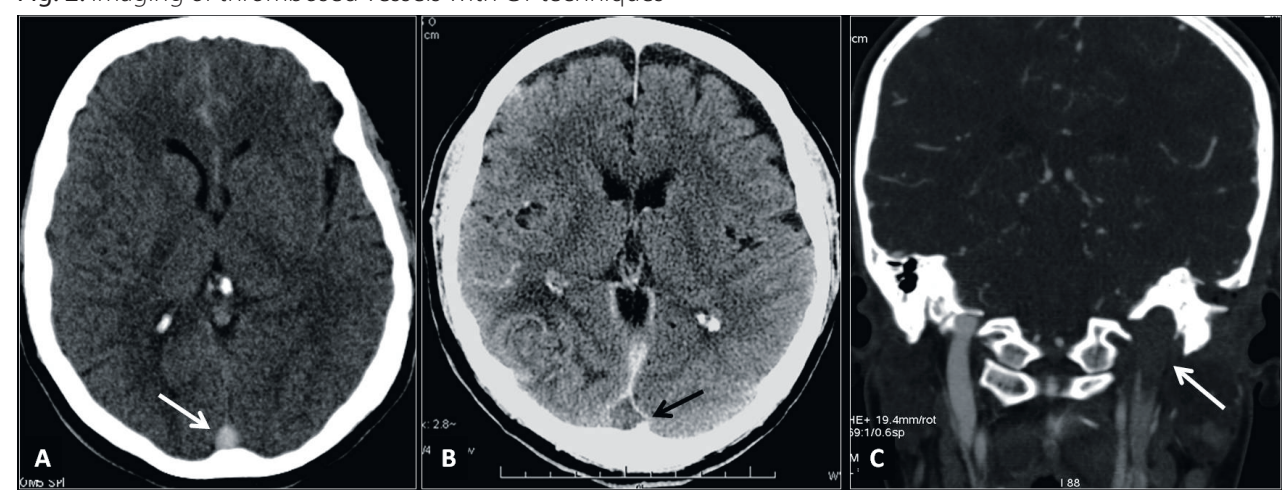

$\mathrm{a}, \mathrm{b}$ - thrombosis of the posterior aspect of the superior sagittal sinus. The thrombosed sinus is visible as a hyperdense vessel (arrow) on a non-enhanced CT image (a) or as a filling defect (arrow) on the contrast enhanced CT image (b); c- a coronal CT angiography image showing a large filling defect within a thrombosed left internal jugular vein (arrow).

Fig. 3. Imaging of thrombosed sinuses and cortical veins with MR techniques without contrast injection

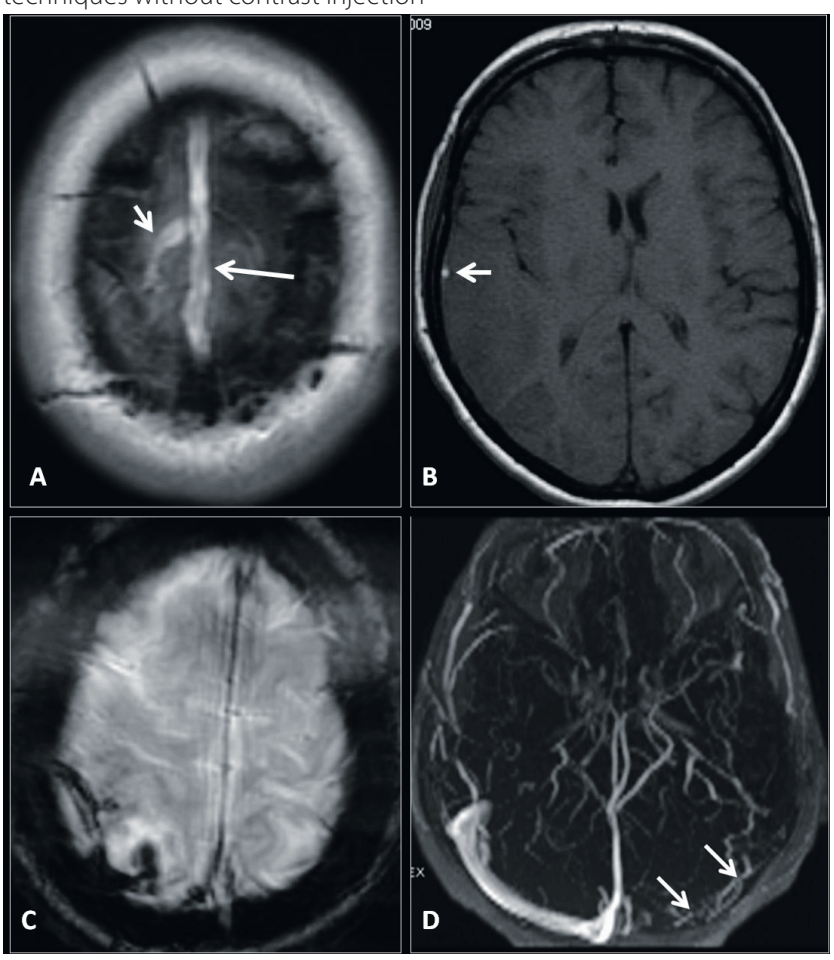

a, b-T1-weighted images showing hyperintense thrombosed superior sagittal sinus (large arrow) and cortical veins (small arrows); c - Susceptibility Weighted Image showing very low signal within a thrombosed cortical vein in the right parietal area (arrow); $d$ - MR venography without contrast injection showing a complete lack of signal in the thrombosed left transverse sinus (arrows).

subjects required 2, 3 or even 4 imaging examinations for the final diagnosis to be reached (Table 4).

The retrospective analysis of all neuroimaging examinations revealed CVT of the superficial venous system in all subjects with a coexisting thrombosis of the deep venous system in one case (Tables 1-3). In the superficial CVT, thrombosed vessels were found bilaterally in 3 patients, exclusively on the left side in 4 patients and on the right side in 4 patients. In the superficial CVT, the thrombosed ves- sels were superior sagittal sinus (6 patients), transverse sinus (9 subjects), sigmoid sinus (9 subjects) and internal jugular vein (8 subjects) (Fig. 2, 3). In 7 subjects, cortical veins were also thrombosed such as the vein of Labbé (3 patients), the vein of Trolard (2 patients), small convexity veins (3 patients) and small infratentorial cortical veins (1 patient) (Tables 1-3, Fig. 3 a-c). Parenchymal lesions due to superficial CVT were found in 9 patients, including hemorrhagic infarctions in 6 patients (Table 3 ) and non-hemorrhagic lesions in 3 subjects (Table 2, Fig. 1). One subject developed bilateral cerebral lesions. In 2 subjects, no cerebral lesions were found in the course of superficial CVT (Table 1). In the case of the deep CVT, deep veins and the straight sinus were thrombosed with the non-hemorrhagic lesions involving the left basal ganglia region, left thalamus and the periventricular white matter (Table 2, Fig. 1b).

Follow-up neuroimaging examinations showed no venous recanalization in 2 patients, partial recanalization in 3 subjects and total recanalization of the thrombosed vessels in 5 patients (Tables 1-3). In 1 subject, the status of the vessels was not possible to assess due to the lack of the dedicated vascular imaging. In all patients, brain lesions showed normal evolution in time.

Two patients with non-hemorrhagic lesions with full vessel recanalization showed complete or almost complete regression of the parenchymal changes. None of the non-hemorrhagic lesions underwent secondary hemorrhagic transformation. Despite the rate of recanalization, all hemorrhagic venous infarctions left post-malacic foci within brain parenchyma.

\section{Correlation of the results of neurological and neuroimaging examinations}

The mildest clinical symptoms (isolated headache) were observed in patients without any brain lesions and CVT of internal jugular veins and transverse and sigmoid sinuses. The worst clinical course and outcome were noted in 2 subjects with hemorrhagic infarctions and CVT of the superior sagittal sinuses. Seizures and hemiparesis 
(with or without accompanying headache) were strongly associated with the existence of focalbrain lesions. Patients with non-hemorrhagic lesions showed either seizures or hemiparesis, not both, while patients with hemorrhagic lesions usually showed both seizures and hemiparesis (4 out of 6 subjects), apart from 2 cases in which either seizures or hemiparesis were present. Seizures were noted in 1 out of 3 (33\%) subjects with non-hemorrhagic lesions and in 5 out of 6 (83\%) subjects with hemorrhagic lesions. In all subjects with seizures, brain lesions were located within the cortex of the frontal lobes. Hemiparesis was seen in 2 out of $3(66.6 \%)$ subjects with non-hemorrhagic cortical lesions and in 5 out of 6 (83\%) subjects with hemorrhagic cortical brain lesions (Tables 1-3).

Full recovery without any neurological symptoms was observed in all subjects without any brain lesions, in 1 out of 3 subjects (33\%) with non-hemorrhagic brain lesions in the deep structures and in 1 out of $6(16.6 \%)$ subjects with hemorrhagic lesions located in the right occipital lobe. Secondary epilepsy was observed in 1 patient with non-hemorrhagic cortical lesions, even though it disappeared completely in the follow-up examinations, and in 4 patients with hemorrhagic infarctions and post-malacic foci within the cortex. Persistent hemiparesis was observed in 1 subject with non-hemorrhagic infarction and in 3 subjects with hemorrhagic lesions and post-malacic foci within the cortex (Tables 1-3).

A coexistence of the superficial and deep CVT did not worsen the neurological state of the patients who fully recovered after the treatment.

There was no direct association between the rate of recanalization of the thrombosed vessels and the neurological recovery. Out of 5 patients with total vessel recanalization, 2 subjects showed full neurological recovery and the other 3 with non-hemorrhagic and hemorrhagic brain lesions developed symptomatic epilepsy. Out of 3 subjects with partial vessel recanalization, 2 fully recovered and 1 patient with hemorrhagic brain lesion developed symptomatic epilepsy and hemiparesis. Two subjects with no vessel recanalization and brain infarcts developed persistent hemiparesis and seizures (Tables 1-3).

There was no direct association between the delay in the onset of the thrombolytic treatment and neurological outcome. In patients who fully recovered, the onset of the treatment ranged between 1 and 13 days (mean 5.25 days), and in patients who developed persistent neurological symptoms it ranged between 1 and 21 days (mean 7.4 days).

\section{Discussion}

The clinical picture of CVT is usually non-specific and may mimic other neurological pathologies. In the presented group of patients, the most frequent symptoms were also non-specific and included headache, seizures and hemiparesis. Headache is reported to be the most frequent initial symptom of CVT, which was also noted in the group of our patients and can be either isolated or accompanied by other symptoms. Isolated headache is not so common (reported in 14\% of cases) and was present in 1 of our patients. ${ }^{12}$ It is a diagnostic challenge and it should always raise the suspicion of CVT, especially in patients with high risk factors. An analysis of risk factors may be helpful in emergency settings, especially history of estrogen treatment and peripartal period in young women. Neoplastic disease or head trauma, which were major risk factors also found in our patients, should raise the suspicion of CVT.

It has to be stressed that there are no laboratory findings or tests that would be easy to do in emergency settings and could confidently rule out CVT. The value of D-dimers was tested in several studies and was reported to be normal in 4-26\% of CVT patients. ${ }^{13,14}$ In our study, these numbers are even higher since the elevated D-dimer concentration was noted in only 5 out of 11 patients (45\%), which makes this test unreliable for confirming or rejecting the diagnosis of CVT. After the diagnosis of CVT is established, it is important to perform testing for congenital thrombophilia. The presence of congenital thrombophilia potentiates the risk of CVT, which was also the case in our 3 female patients who developed CVT due to combined abnormalities of the thrombotic system and either oral contraception or cesarean section. ${ }^{1}$ It is important to diagnose congenital thrombophilia to protect the patient from future potential CVT incidents and to look for this disorder in the patient's family members so that preventive measures can also be taken in this group.

Since the clinical picture including symptoms and laboratory findings is often very non-specific, the role of neuroimaging is crucial to raise the suspicion of CVT. Usually the first imaging method is a CT examination of the brain. It has to be stressed that, similarly to the nonspecific neurological symptoms, CT images may also be difficult to interpret and pose a diagnostic problem which was also noted in the cases of our patients.

According to the literature, only in $25 \%$ of cases can CVT be visualized with an unenhanced CT as an increased density within a thrombosed vein. ${ }^{8,15}$ A retrospective detailed evaluation of our cases showed these signs in 8 out of 11 emergency $\mathrm{CT}$ examinations but only in 2 cases it was correctly reported. It has to be stressed that these signs may be difficult to spot, require an experienced radiologist and may be easily overlooked especially in the cases of CVT within small cortical veins, or subjects with elevated hematocrit and in the coexistence of subarachnoid hemorrhage or subdural hematoma. Administration of iodinated contrast agents improves the detection of a thrombus in CT and it helped to diagnose CVT in 2 of our subjects. The clot within a vessel is visible as a filling defect, which in the case of a thrombus within a superior sagittal sinus is known as 
an empty delta sign. ${ }^{8,15}$ The best technique for a direct detection of thrombosis using the CT technique is CT venography. It was used to diagnose CVT in 1 of our subjects after inconclusive contrast-enhanced CT. However, this examination is associated with a high dose of radiation and requires an iodinated contrast agent, which may sometimes cause serious side effects.

Changes within brain parenchyma in the course of CVT can be varied, ranging from small areas of decreased density to large hemorrhagic lesions. However, it has to be stressed that even in the course of CVT involving large venous sinuses, sometimes no evident lesions within the brain can be found in CT imaging. ${ }^{1,8,9}$ This was the case in 2 of our patients with CVT of transverse and sigmoid sinuses in whom no visible changes within brain parenchyma were detected either in emergency $\mathrm{CT}$ or any of the follow-up neuroimaging examinations. In another 2 subjects, emergency CT examinations were reported normal since no cerebral lesions were visible initially. They appeared a few days later in the follow-up examinations and the only pathological findings in the retrospective analysis of the emergency CT examinations were hyperdense deep veins in one case and a hyperdense single cortical vein in the other case, which were overlooked in the emergency settings.

Suspicion of CVT should always be raised by bilateral hypodense areas within deep structures such as thalamus and basal ganglia, which are typical of deep CVT. ${ }^{8}$ Other cerebral lesions with high suspicion of CVT are hemorrhagic lesions in the brain, located peripherally within the cortex, which do not correspond to the territories supplied by arterial vasculature, and especially when they are bilateral. ${ }^{8}$ On the other hand, such hemorrhagic lesions are often confused with hemorrhagic arterial infarcts, cerebral contusions and bleeding due to a tumor or vascular malformations, which was also the problem in the group of our patients. In our study, none of the hemorrhagic lesions were correctly reported as hemorrhagic infarctions due to CVT.

In the case of suspected CVT based on a standard CT scan, the next examinations which could confirm the diagnosis may be CT venography or MRI. In 3 of our patients, it was the contrast enhanced MRI which ultimately diagnosed CVT. Parenchymal changes are better visible in MRI than in CT. ${ }^{9}$ In addition to better detection of brain lesions, MRI allows for an unambiguous differentiation of venous from arterial strokes, since the latter show diffusion restriction in DWI. ${ }^{16}$ Another advantage of MRI is its capability to image thrombosed veins and venous sinuses, even in the examinations without contrast application, with greater sensitivity than unenhanced CT examinations, and in the case of thrombosis of cortical veins with greater sensitivity than CT venography. ${ }^{8}$ In unenhanced MRI, the signal intensity of venous thrombi varies according to their age and is related to the paramagnetic effects of the products of hemoglobin breakdown. A venous thrombus in the acute stage ( $0-5$ days) may be very poorly visible, while in the subacute stage its signal is predominantly hyperintense on all images (T1, T2, FLAIR, DWI), which is associated with the presence of methemoglobin. ${ }^{1,8}$ Hyperintense veins are observed in over $50 \%$ of patients with CVT. MRI without contrast administration is a particularly useful tool for the detection of thrombosis of small cortical veins, especially with the use of T1-weighted, FLAIR, $\mathrm{T}^{*}$ gradient or susceptibility weighted images (SWI). ${ }^{1,17}$ Administration of the contrast agent in MRI, similar to CT imaging, improves the detection of CVT. MR venography may be performed with or without administration of contrast medium. In MR venography without contrast administration, chronic, peripherally located thrombi or partially recanalized thrombi with preserved blood flow within the sinus will not be visible. In such cases, the best imaging technique will be MR venography with contrast injection or CT venography, which show a chronic thrombus as a filling defect within a contrasted vessel. ${ }^{18,19}$

At present, DSA, which is still regarded as the gold standard for diagnosing vascular pathologies, is only rarely performed in CVT because of its invasiveness. ${ }^{9}$ It is only used in diagnostically difficult cases. In our study, DSA was performed in 2 cases. In 1 patient, DSA was performed to reach the final diagnosis of CVT. In this case, venous thrombosis included the anterior aspect of the superior sagittal sinus, which was not seen in the earlier performed examinations such as CT, MRI with contrast and CT venography, even in the retrospective analysis. It the other patient, DSA was performed after the false suspicion of the bleeding vascular malformation based on an emergency CT examination. It has to be stressed that initial radiological diagnosis has an impact on further diagnostic procedures and the selection of subsequent imaging examinations, as shown in Table 4. In our study, a radiological suspicion of a vascular malformation resulted in DSA, which is an invasive procedure and could have been abandoned in this case.

The other aim of our study, apart from the analysis of the clinical and radiological diagnostic challenges, was to analyze the associations between the clinical course and outcome of the patients and the location of the venous occlusion, type of parenchymal lesions and rate of vessel recanalization.

In our study, all patients developed thrombosis of the superficial venous system, while only 1 person (9\%) also exhibited features of deep venous system thrombosis. This is consistent with the literature reports, in which the incidence of CVT of the superficial system, including the dural sinuses and cortical veins, is estimated to be approx. 67\%, and in the case of the deep system, including internal cerebral veins, vein of Galen and the sinus rectus, at about $32 \%{ }^{8}$ According to the literature, the most often involved sinus is the superior sagittal sinus (63\%), followed by the transverse sinus (57\%), then sigmoid and 
rectus (each 15\%). ${ }^{8}$ In our material, CVT of transverse and sigmoid sinuses was the most frequent ( $80 \%)$, followed by superior sagittal sinus (40\%) and rectus (20\%). An interesting observation in our study is the high percentage (55.5\%) of thrombosis of cortical veins. In the literature, thrombosis of cortical veins is estimated at around 6\%, but in our opinion this low percentage is associated with an underestimation of this phenomenon due to difficulties with imaging thrombosis within these small vessels. In our study, we noticed that coexistence of the deep venous thrombosis did not worsen the clinical course of the patient, who presented with mild symptoms and in the end fully recovered without any persisting neurological symptoms. According to the literature, when the deep cerebral venous system is occluded, the clinical picture is usually more severe with coma and motor deficits, which are usually bilateral, though more limited thrombosis of the deep venous system without parenchymal lesions can cause relatively mild symptoms ${ }^{20}$ Our patient with deep CVT developed parenchymal lesions but they were not hemorrhagic and disappeared completely in the followup examinations.

In our study, the type of cerebral lesions had the strongest influence on the clinical outcome of the patients. In the course of CVT, brain hemorrhagic lesions occur more frequently than non-hemorrhagic. ${ }^{8}$ They leave areas of malacia or cavities in the brain tissue, which have an impact on the occurrence of late clinical symptoms. In our study, 5 out of 6 subjects with hemorrhagic brain lesions developed either persistent secondary epilepsy, hemiparesis or both. The only person with hemorrhagic lesions who fully recovered was the male subject with parenchymal lesion in the right occipital lobe and the symptoms of transient visual phenomena and mild left-sided hemiparesis. It has to be stressed that non-hemorrhagic changes in the brain in the course of CVT may be either true irreversible necrotic lesions or areas of edema which may resolve completely. ${ }^{8}$ In patients with real irreversible venous infarcts, neurological defects are reported to be more frequent. ${ }^{3}$ In our study group, 2 patients showed edematous lesions which resolved completely in the follow-up examinations - in one case without leaving any persistent neurological symptoms (patient with deep CVT), while in the other case causing persistent secondary epilepsy, probably due to irreversible damage of the frontal cortex not visible in the follow-up imaging examinations.

In our study, we also looked at the correlation of the rate of vessel recanalization and the clinical outcome. Thrombus recanalization occurs at different rates in patients, which is reported to have an impact on clinical symptoms and outcome. Endogenous thrombolysis often coexists with the processes of thrombosis, which is reflected by the fluctuating course of clinical symptoms in CVT. ${ }^{21}$ Complete recanalization occurred in 5 and partial recanalization in 3 patients. Total recanalization was not necessary for a very good final outcome. In our study, 2 out of 3 subjects with only partial recanalization showed full neurological recovery and 3 with total recanalization but also with parenchymal lesions were left with persistent neurological deficits. Thus, in our opinion, the factors which influence the clinical outcome the most are the presence and type of cerebral lesions.

\section{Conclusions}

Due to non-specific clinical symptoms and the results of laboratory tests as well as very diverse radiological appearance, the diagnosis of CVT is still a great challenge for neurologists and radiologists. Young age, female gender and risk factors such as oral contraceptives, cancer or cranio-cerebral trauma as well as non-specific symptoms such as headache or seizures should always arouse a clinical suspicion of CVT. Neuroimaging is of crucial importance for the final diagnosis and clinical outcome of the patient. The most difficult and challenging patients are those with discrete radiological symptoms, easy to overlook, or with brain lesions mimicking other entities, e.g., tumors, contusions, arterial ischemia or vascular malformations. Suspicion of CVT should be raised by hemorrhagic lesions, particularly located within the cortex or bilaterally within the deep structures. After emergency CT, MRI is the next examination recommended to confirm the diagnosis, especially in the case of young people or in the subacute phase of CVT. In the chronic phase, CT or MR venographies are the best methods to assess the patency of thrombosed vessels. The factor which influences the clinical course and outcome the most is the location and type of brain lesions, with hemorrhagic cortical infarctions bringing the worst prognosis and being associated with the highest rate of persistent neurological deficits. In our opinion, quick diagnosis before parenchymal hemorrhagic lesions are visible on CT is of crucial importance and requires a constant alertness and good cooperation of neurologists and radiologists, especially in emergency settings.

\section{References}

1. Bousser MG, Ferro JM. Cerebral venous thrombosis: An update. Lancet Neurol. 2007;6:162-170.

2. Saposnik G, Barinagarrementeria F, Brown RD, et al. Diagnosis and Management of Cerebral Venous Thrombosis. A Statement for Healthcare Professionals From the American Heart Association / American Stroke Association. Stroke. 2011;42:1158-1192.

3. Masuhr F, Mehraein S, Einhaupl K. Cerebral venous and sinus thrombosis. J Neurol. 2004;251:11-23.

4. Stam J. Thrombosis of the cerebral veins and sinuses. N Engl J Med. 2005;352:1791-1798.

5. Appenzeller S, Zeller CB, Annichino-Bizzachi JM, et al. Cerebral venous thrombosis: Influence of risk factors and imaging findings on prognosis. Clin Neurol Neurosurg. 2005;107:371-378.

6. Bousser MG, Crassard I. Cerebral venous thrombosis, pregnancy and oral contraceptives. Thromb Res. 2012;130(suppl 1):19-22.

7. Ferro JM, Canhao P, Stam J, Bousser MG, Barinagarrementeria F, ISCVT Investigators. Prognosis of cerebral vein and dural sinus thrombosis: Results of the International Study on Cerebral Vein and Dural Sinus Thrombosis (ISCVT). Stroke. 2004;35:664-670. 
8. Leach J, Fortuna RB, Jones BV, Gaskill-Shipley MF. Imaging of cerebral venous thrombosis: Current techniques, spectrum of findings, and diagnostic pitfalls. RadioGraphics. 2006;26:19-43.

9. Qu H, Yang M. Early imaging characteristics of 62 cases of cerebral venous sinus thrombosis. Exper and Therap Med. 2013;5:233-236.

10. Yii IY, Mitchell PJ, Dowling RJ, Yan B. Imaging predictors of clinical deterioration in cerebral venous thrombosis. J Clin Neurosci. 2012;19:1525-1529.

11. Einhaupl K, Bousser MG, de Bruijn SF, et al. EFNS guideline on the treatment of cerebral venous and sinus thrombosis. Eur J Neurol. 2006;13:553-559.

12. Cumurciuc R, Crassard I, Sarov M, Valade B, Bousser MG. Headache as the only neurological sign of cerebral venous thrombosis: A series of 17 cases. J Neurol Neurosurg Psychiatry. 2005;76:1084-1087.

13. Talbot K, Wright M, Keeling D. Normal D-dimer levels do not exclude the diagnosis of cerebral venous thrombosis. J Neurol. 2002;249:1603-1604.

14. Crassard I, Soria C, Tzurio Ch, et al. A negative D-dimer assay does not rule out cerebral venous thrombosis: A series of 73 patients. Stroke. 2005:36:1716-1719.

15. Viraponge C, Cazenave C, Quisling R, Sarwar M, Hunter S. The empty delta sign: Frequency and significance in 76 cases of dural sinus thrombosis. Radiology. 1987;162:779-785.

16. Ducreux D, Oppenheim C, Vandamme X, et al. Diffusion-weighted imaging pattern of brain damage associated with cerebral venous thrombosis. AJNR. 2001;22:261-268.

17. Selim M, Fink J, Llinfante I, Kumar S, Schlaug G, Caplan LR. Diagnosis of cerebral venous thrombosis with echo-planar T2*-weighted magnetic resonance imaging. Arch Neurol. 2002;59:1021-1026.

18. Farb RI, Scott JN, Willinsky RA, Montanera WJ, Wright GA, terBrugge KG. Intracranial venous system: Gadolinium-enhanced threedimentional MR venography with auto-triggered elliptic centricordered sequence - initial experience. Radiology. 2003;226:203-209.

19. Vogl TJ, Bergman C, Villringer A, Einhaupl K, Lissner J, Felix R. Dural sinus thrombosis: Value of venous MR angiography for diagnosis and follow-up. AJR. 1994;162:1191-1198.

20. van der Bergh WM, van der Schaaf I, van Gijn J. The spectrum of presentation of venous infarction caused by deep cerebral vein thrombosis. Neurology. 2005;65:192-196.

21. Stolz E, Trittmacher S, Rahimi A, et al. Influence of recanalization on outcome in dural sinus thrombosis: A prospective study. Stroke. 2004;35:544-547. 